\title{
Determinants of the Early Childhood Development Index among children aged < 5 years in Bangladesh, Costa Rica and Ghana: a comparative study
}

Iqramul Haq, ${ }^{1}$ Md. Ismail Hossain, ${ }^{2}$ Maliha Afroj Zinnia, ${ }^{3}$ Md Rifat Hasan ${ }^{2}$ and Imru-Al-Quais Chowdhury ${ }^{4}$

${ }^{1}$ Department of Agricultural Statistics, Sher-e-Bangla Agricultural University, Dhaka, Bangladesh. (Correspondence to: Iqramul Haq , iqramul.haq@ sau.edu.bd). ${ }^{2}$ Department of Statistics, Jagannath University, Dhaka, Bangladesh. ${ }^{3}$ Department of Pharmacy, East West University, Dhaka, Bangladesh. ${ }^{4}$ Armed Forces Medical Institute, Dhaka Cantonment, Bangladesh.

\begin{abstract}
Background: Early child development is a crucial factor for children that controls health and well-being in later life.

Aims: To determine the influence of sociodemographic factors on the Early Child Development Index (ECDI) among children aged $<5$ years.

Methods: The analysis was performed using cross-sectional survey data from 2019, 2017-2018 and 2018 Multiple Indicator Cluster Surveys from Bangladesh, Ghana and Costa Rica, respectively. We used the $\chi^{2}$ test for bivariate analysis and binary logistic regression model for multivariate analysis for all 3 countries. All the statistical analyses were performed with IBM SPSS version 25 and R version 4.0.0.

Results: Child age and sex, followed by maternal education level, economic status, child nutritional status, reading children's books, and maternal functional difficulties had the greatest effect on ECDI. Children aged 36-47 months had lower odds of development than those aged 48-59 months, and boys had lower odds of development than girls in Bangladesh, Costa Rica and Ghana. Urban children had lower odds of development than rural children in Costa Rica but higher odds in Ghana.

Conclusion: We recommend that governments should take the necessary steps to enhance children's early development and well-being in all 3 countries by raising education, improving economic conditions and providing balanced nutrition. Keywords: child development, child nutrition, child mortality, cognitive, early childhood development

Citation: Haq I; Hossain MI; Zinnia MA; Hasan MR; Chowdhury I. Determinants of the Early Childhood Development Index among children aged < 5 years in Bangladesh, Costa Rica and Ghana: a comparative study. East Mediterr Health J. 2021;27(11):1069-1077. https://doi.org/10.26719/emhj.21.055

Received: 18/11/20; accepted: 25/04/21

Copyright (c) World Health Organization (WHO) 2021. Open Access. Some rights reserved. This work is available under the CC BY-NC-SA 3.0 IGO license (https://creativecommons.org/licenses/by-nc-sa/3.o/igo)
\end{abstract}

\section{Introduction}

Early childhood development (ECD) comprises the physical, cognitive, motor and socioemotional growth of children up to 8 years of age $(1,2)$. Approximately $20 \%$ of children aged $<5$ years develop slowly, $5 \%$ show signs of wasting, and $11 \%$ are underweight. Child development starts during conception and the initial years are significant because the brain advances most rapidly during this time and builds capacity for improvements, as this foundation is involved in health and quality of life (3). A child's brain improves by $90 \%$ within the first 5 years, thus these years are critical (4). The Sustainable Development Goals (SDGs) Agreement indicates that ECD will be a priority for the 21st century (5). The new sustainable development agenda includes 1 target (4.2) relevant for ECD. Target 4.2 states that, by 2030, countries should ensure that all girls and boys have access to quality early childhood development, care and preprimary education so that they are ready for primary education (5). However, the contributions of the SDGs to ECD are wider than this education-oriented goal. The key to achieving at least 7 of the SDGs is to strengthen ECD by tackling poverty, hunger, health (including child mortality), education, gender, water and sanitation, and inequality.

Children must be provided with responsive care, balanced nutrition, nurturing, and a safe environment to live, learn, grow and develop to full potential (6). Several studies conducted in 2007 concluded that $>200$ million children under the age of 5 years did not achieve their developmental potential in low- and middleincome countries (LMICs) as a result of nutritional deficiencies and insufficient learning opportunities (79). Economic depression and climate diversity have also raised the number of children affected $(10,11)$. Biological and psychosocial risk factors accompanied by poverty lead to an imbalance in ECD that threaten educational attainment and adult productivity $(7,12)$.

High-quality preschool education has a significant influence on cognitive and socioemotional development $(13,14)$. Costa Rica has become a global leader in ECD by making it mandatory for all young children to enrol in preprimary education (4). In Costa Rica, preschool allowances are increased, particularly in kindergarten, and to be admitted to the first-grade school, 3- and 4-year-old children must attend first-grade preprimary 
education $(15,16)$. One in 5 children in Ghana experiences stunted growth due to insufficient nutrition, recurrent illness and an unhealthy environment, resulting in disrupted physical, social and cognitive development that successively affects their early learning, school performance, and ultimately, their socioeconomic development (17). In 2007, Ghana launched a 2-year preprimary education for children between 3 and 4 years of age. In recent years, preprimary school attendance has increased and education in Ghana has improved $(18,19)$.

In Bangladesh, understanding of ECD is still emerging as a result of severe constraints, such as poverty, lack of qualified educators and health professionals, as well as funding (20). Most parents have little knowledge of childcare and rearing, and the Bangladeshi Ministry of Women's and Children's Affairs and the Ministry of Health and Family Welfare have formed the Centre of Early Childhood Care and Development. The Centre aims to provide essential elements of child growth, such as early nutrition, stimulation, security and learning (21). While most of the activities of the Centre are targeted at preschool children, a few are aimed at parents or children under 3 years of age (21).

Several studies have shown that the development of many children aged $<5$ years has not progressed in the right way in LMICs due to many factors such as poverty and education. The present study aimed to measure the effects of various sociodemographic and economic factors on ECD, and to determine which risk factors are associated with Early Childhood Development Index
(ECDI) in 3 LMICs, Bangladesh, Costa Rica and Ghana. This should provide researchers and policy-makers with updated insights on early childhood development and help them develop appropriate guidance and programmes.

\section{Methods}

\section{Study design and data sources}

The analysis was performed on cross-sectional survey data obtained from the 2019 Multiple Indicator Cluster Survey (MICS) for Bangladesh, 2018 MICS for Costa Rica, and 2017-2018 MICS for Ghana. For survey sample selection, we used a 2-stage stratified cluster sampling approach and the same sampling frame was adopted for the Bangladesh Census of Population and Housing, 2011 (22), the Housing Sample Frame (Marco Muestral de Viviendas), 2011 (for Costa Rica) (23), and Population and Housing Census, 2010 (for Ghana) (19). Household and independent (mothers) questionnaires were utilized to collect information about children aged $<5$ years. Following weighting of the samples, 23099 children aged $<5$ in Bangladesh, 370096 in Costa Rica, and 8879 in Ghana were included in this study. The geographical locations of the children in the 3 countries are shown in Figure 1.

\section{Dependent variable}

The dependent variable was ECD among children aged 36-59 months and was calculated by using 4 domains $(19,22,23)$ : literacy-numeracy, physical, social-emotional,

\section{Figure 1 Map showing the geographical locations of samples in 3 countries. ECDI = Early Child Development} Index

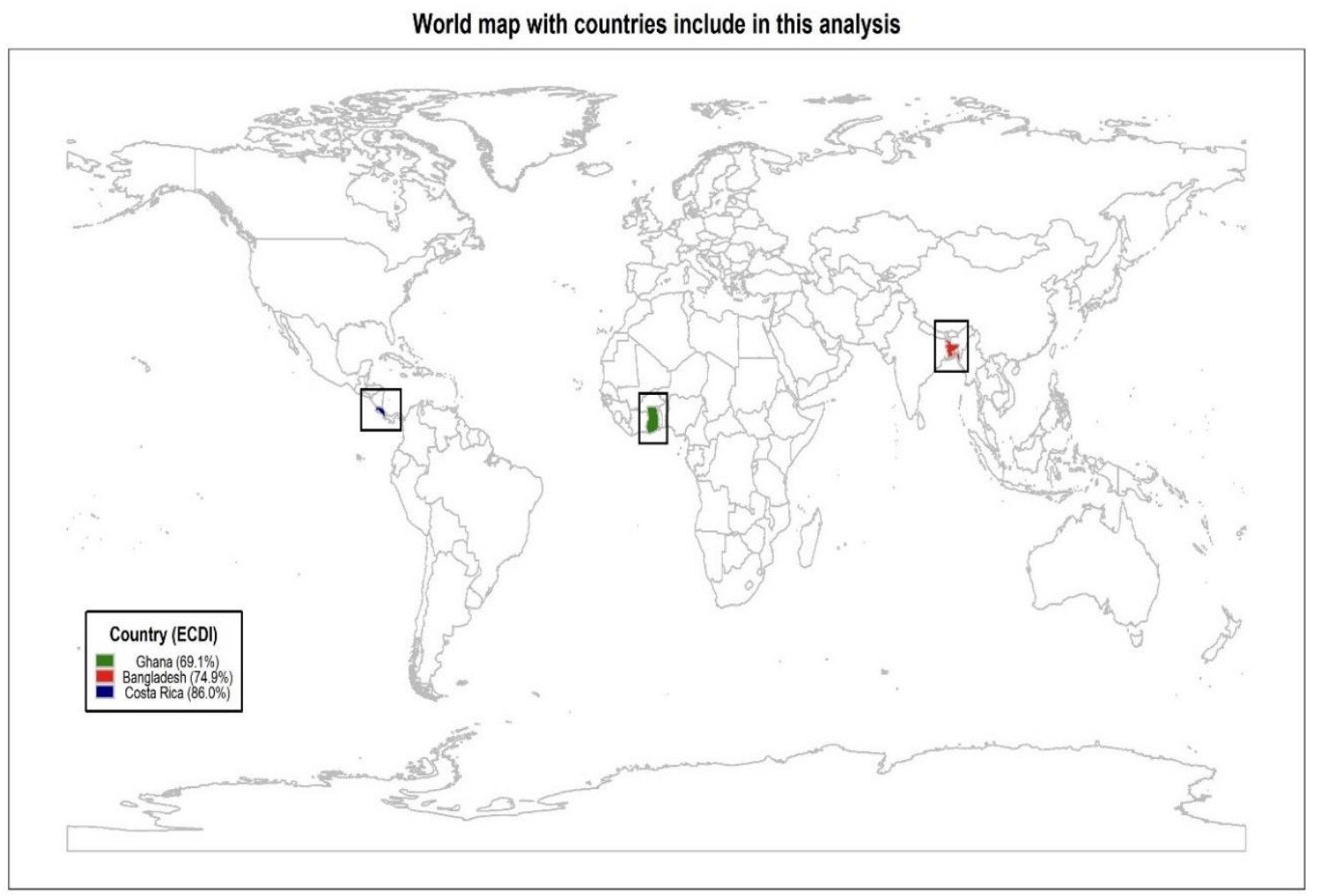


and learning. To distinguish domain compliance for each child $i$ aged 36-59 months in country $j$ (Bangladesh, Costa Rica or Ghana), for domain $r$ (literacy-numeracy, physical, social-emotional, or learning),

$d_{i, j, r}=\left\{\begin{array}{l}1 ; \text { if child } i \text { in country } j \text { is on track in domain } r \\ 0 ; \text { if child } i \text { in country } j \text { is not on track in dom }\end{array}\right.$

0 ; if child $i$ in country $j$ is not on track in domain $r$

ECD compliance was defined as child $i$, in country $j$, that satisfied at least 3 of 4 domains $r$. That is,

$$
E C D_{i, j}=\left\{\begin{array}{l}
1 ; \text { if } \sum_{\substack{r=1 \\
0}}^{4} d_{i, j, r} \geq 3 \\
\text { Otherswise }
\end{array}\right.
$$

For the aim of the study, children whose development was on track in at least 3 domains were categorized as 1 and the remainder as 0 .

$E C D I=\{1 ;$ Yes, developmentally on track in at least 3 domains $E C D I=\{0 ;$ No, not developmentally on track in at least 3 domains

The created binary variable was considered as the dependent variable for our study.

\section{Independent variable}

Besides the dependent variable, we also considered child age, childsex, residence, maternal education, economic status, child nutritional status, reading children's books, and maternal functional difficulties as potential factors for early development among children aged $<5$ years in Bangladesh, Costa Rica and Ghana. Descriptions and classifications of the study explanatory variables are listed in Table 1.

\section{Data analysis}

The IBM SPSS version 25 and $R$ version 4.0.0 were used for data management, analysis and geographical mapping. Appropriate statistical methods for data analysis were used to obtain different objectives of this study. To examine the association between dependent variables and selected covariates, we applied the $\chi^{2}$ test for bivar- iate analysis. The binary logistic regression model in a multivariable setup was applied to identify factors that contributed to ECDI among children aged $<5$ years.

\section{Results}

\section{ECDI characteristics of children aged $<5$ years}

The overall ECDI was $69.1 \%$ in Ghana, $74.9 \%$ in Bangladesh, and $86.0 \%$ in Costa Rica during this study period.

\section{Effect of sociodemographic factors on ECD}

Children's age and sex, residence, maternal education, economic status, child nutritional status, reading children's books, and maternal functional difficulties were significantly correlated with ECD in Bangladesh, Costa Rica and Ghana (Table 2).

\section{Collinearity for independent variable}

Multicollinearity statistics for all explanatory variables are shown in Table 3. In a regression model, multicollinearity is observed as high levels of interdependence among predictors, which can be particularly burdensome for studies. Multicollinearity is indicated by a threshold of 5 or 10 for variance inflation factor (VIF) and 0.1 or 0.2 for tolerance. Table 3 shows that there was no multicollinearity in the present study. The range of VIF values was 1.003-1.342 for Bangladesh, 1.007-1.290 for Costa Rica and 1.006-1.629 for Ghana.

\section{Multivariate analysis for identifying factors}

Table 4 illustrated the odds of child development status among children aged 3-5 years in Bangladesh, Costa Rica and Ghana. For all countries in the model, significant $(P<0.001, P<0.01$ and $P<0.05)$ odds ratios for child age, child sex, maternal education, economic status, reading children books, and maternal functional difficulties were distinguished. Several risk factors were not significant for different countries; in particular, residence for Bangladesh, severe child nutritional status and moderate nutritional status for Ghana and Bangladesh, respectively.

\begin{tabular}{ll}
\hline Table 1 Summary of explanatory variables \\
Variable & Categorization \\
Child age, months & $36-47,48-59$ \\
Child sex & Male or female \\
Residence & Urban or rural \\
Maternal education & None education, primary education, secondary and above education \\
Economic status & Poor, middle or rich \\
Child nutritional status & In 2019, MICS Bangladesh used weight and height calculations to explore the nutritional status of children \\
& aged $<5$ years and used common measures of height for age $Z$ score, weight for age $Z$ score, and weight \\
& for height $Z$ score to determine the nutritional health of children. We used weight for age $Z$ score as child \\
& nutritional status variable and categories as: \\
& severely malnourished: WAZ $<-3.0$ \\
& moderately malnourished: $-3.0<$ WAZ $<-2.01$ \\
nourished: WAZ $>-2.01$
\end{tabular}


Table 2 Bivariate analysis of Early Child Development Index among children aged 36-59 months by selected background characteristics in Bangladesh, Costa Rica and Ghana

\begin{tabular}{|c|c|c|c|c|c|c|}
\hline \multirow[t]{3}{*}{ Characteristics } & \multicolumn{6}{|c|}{$\begin{array}{c}\text { Children developmentally on track in } \\
\text { at least } 3 \text { domains }\end{array}$} \\
\hline & \multicolumn{2}{|c|}{ Bangladesh } & \multicolumn{2}{|c|}{ Costa Rica } & \multicolumn{2}{|c|}{ Ghana } \\
\hline & No (\%) & Yes $(\%)$ & No (\%) & Yes (\%) & No (\%) & Yes (\%) \\
\hline \multicolumn{7}{|l|}{ Child Age } \\
\hline 36-47 months & 31.2 & 68.8 & 15.1 & 84.9 & 36.6 & 63.4 \\
\hline 48-59 months & 18.8 & 81.2 & 13.0 & 87.0 & 24.7 & $75 \cdot 3$ \\
\hline$P$ & \multicolumn{2}{|c|}{$<0.001$} & \multicolumn{2}{|c|}{$<0.001$} & \multicolumn{2}{|c|}{$<0.001$} \\
\hline \multicolumn{7}{|l|}{ Child Sex } \\
\hline Male & 28.5 & 71.5 & 17.4 & 82.6 & 34.9 & 65.1 \\
\hline Female & 21.5 & 78.5 & 10.5 & 89.5 & 27.1 & 72.9 \\
\hline$P$ & \multicolumn{2}{|c|}{$<0.001$} & \multicolumn{2}{|c|}{$<0.001$} & \multicolumn{2}{|c|}{$<0.001$} \\
\hline \multicolumn{7}{|l|}{ Residence } \\
\hline Urban & 21.9 & 78.1 & 13.3 & 86.7 & 19.6 & 80.4 \\
\hline Rural & 26.0 & 74.0 & 15.5 & 84.5 & 39.2 & 60.8 \\
\hline$P$ & \multicolumn{2}{|c|}{$<0.001$} & \multicolumn{2}{|c|}{$<0.001$} & \multicolumn{2}{|c|}{$<0.05$} \\
\hline \multicolumn{7}{|l|}{ Maternal education } \\
\hline None & 31.5 & 68.5 & 25.3 & 74.7 & 40.0 & 60.0 \\
\hline Primary & 30.6 & 69.4 & 17.8 & 82.2 & 30.0 & 70.0 \\
\hline Secondary and above & 21.7 & 78.3 & 12.6 & 87.4 & 12.9 & 87.1 \\
\hline$P$ & \multicolumn{2}{|c|}{$<0.001$} & \multicolumn{2}{|c|}{$<0.001$} & \multicolumn{2}{|c|}{$<0.001$} \\
\hline \multicolumn{7}{|l|}{ Economic status } \\
\hline Poor & 30.2 & 69.8 & 16.8 & 83.2 & 40.7 & $59 \cdot 3$ \\
\hline Middle & 24.6 & 75.4 & 17.1 & 82.9 & 33.1 & 66.9 \\
\hline Rich & 20.0 & 80.0 & 7.1 & 92.9 & 17.4 & 82.6 \\
\hline$P$ & \multicolumn{2}{|c|}{$<0.001$} & \multicolumn{2}{|c|}{$<0.001$} & \multicolumn{2}{|c|}{$<0.001$} \\
\hline \multicolumn{7}{|l|}{ Child nutritional status } \\
\hline Severely malnourished & $32.3 \%$ & 67.7 & $55.6 \%$ & 44.4 & 34.1 & 65.9 \\
\hline Moderately malnourished & 27.2 & 72.8 & 12.9 & 87.1 & 37.7 & 62.3 \\
\hline Nourished & 24.0 & 76.0 & 13.0 & 87.0 & 30.0 & 70.0 \\
\hline$P$ & \multicolumn{2}{|c|}{$<0.001$} & & & & \\
\hline Reading children's books & & & & & & \\
\hline$\geq 3$ & 14.3 & 85.7 & 8.9 & 91.1 & 12.9 & 87.1 \\
\hline$<3$ & 26.7 & 73.3 & 20.2 & 79.8 & 33.5 & 66.5 \\
\hline$P$ & & & & & & \\
\hline Maternal functional difficul & & & & & & \\
\hline Yes & 36.5 & 63.5 & 23.0 & 77.0 & 49.5 & 50.5 \\
\hline No & 25.0 & 75.0 & 13.4 & 86.6 & 29.0 & 71.0 \\
\hline$P$ & & & & & & \\
\hline
\end{tabular}

The results obtained from Bangladesh showed that children aged 36-47 months had a significantly lower ECDI compared children aged 48-59 months. In Costa Rica and Ghana, children aged 36-47 months were 15 and $43 \%$ less developmentally on track in at least 3 domains compared with children aged 48-59 months. Boys had 31,50 and $28 \%$ lower development compared with girls before their fifth birthday in Bangladesh, Costa Rica and Ghana, respectively.

Residence had no significant impact on child development in Bangladesh. In Costa Rica, children aged $<5$ years fulfilled fewer developmental domains. In Ghana, children in urban residences had $83 \%$ more development compared with those in rural residences.

Maternal education was correlated with ECDI in Bangladesh, Costa Rica and Ghana. Children of women without any formal education had 34, 62 and 50\% fewer developmental domains compared to women with secondary and above education in Bangladesh, Costa Rica and Ghana, respectively.

There was a positive association between economic status and ECDI in all three countries. Lower and middle status households were 30 and $16 \%$ less likely to fulfil at least 3 child developmental domains, respectively than women and children from rich families in Bangladesh. There were similar associations in Ghana and Costa Rica.

Child nutritional status had an effect on child development in all 3 countries. The developmental status of babies with severe and moderate malnourishment was 91 and 20\% lower among children aged $<5$ years living in Costa Rica, compared to well-nourished babies and the difference was highly significant. 


\begin{tabular}{|c|c|c|c|c|c|c|}
\hline \multirow[t]{2}{*}{ Characteristics } & \multicolumn{2}{|c|}{ Bangladesh } & \multicolumn{2}{|c|}{ Costa Rica } & \multicolumn{2}{|c|}{ Ghana } \\
\hline & Tolerance & VIF & Tolerance & VIF & Tolerance & VIF \\
\hline Child age & 0.983 & 1.018 & 0.982 & 1.019 & 0.988 & 1.012 \\
\hline Child sex & 0.997 & 1.003 & 0.985 & 1.015 & 0.994 & 1.006 \\
\hline Residence & 0.862 & 1.160 & 0.893 & 1.120 & 0.730 & 1.370 \\
\hline Maternal education & 0.858 & 1.166 & 0.871 & 1.148 & 0.771 & 1.297 \\
\hline Economic status & 0.745 & 1.342 & 0.775 & 1.290 & 0.614 & 1.629 \\
\hline Child nutritional status & 0.973 & 1.028 & 0.993 & 1.007 & 0.986 & 1.014 \\
\hline Reading children's books & 0.930 & 1.075 & 0.865 & 1.156 & 0.795 & 1.258 \\
\hline Maternal functional difficulties & 0.997 & 1.003 & 0.979 & 1.022 & 0.992 & 1.008 \\
\hline
\end{tabular}

In all 3 countries, children aged $<5$ years who read $\geq 3$ children's books had more likelihood of development compared with children who read $<3$ books.

Children whose mothers had functional difficulty were less developed in all 3 countries.

\section{Discussion}

Our study showed that ECDI among children aged $<5$ years was higher in Costa Rica compared with Bangladesh and Ghana. Child development was subject to child age, child sex, residence, maternal education level, economic status, child nutritional status and maternal functional difficulty.

Children aged 48-59 months had a higher ECDI than those aged 36-47 months. Girls developed earlier than boys in all 3 countries. If a child born in Indonesia is of the preferred sex, parents allocate more resources and care towards that child's wellbeing (24). Due to religious, cultural and institutional factors, a preference for male children is widespread in China, India and Bangladesh (24).

We found that place of residence was a significant factor for child development in Costa Rica and Ghana. In Ghana, children from urban areas were more likely to develop at an early age than were children from rural areas, while the opposite was found in Costa Rica. Research from the United Kingdom of Great Britain and Northern Ireland showed that place of residence has a significant impact on child development, while another study from 33 developed countries indicated that urban children usually have better nutritional status than rural children have $(25,26)$. Parents emphasize intellectual and emotional growth in rural areas, while urban parents prioritize social development; however, there is no significant difference in physical growth (27).

Maternal education had a notable impact on child development in all 3 countries. There was a positive association between child development and maternal education. Mothers without formal education had lesswell developed children than those with secondary and higher education. Children of mothers with secondary and higher education were more likely to grow than those of mothers with only primary education. A study of maternal education in rural areas of Bangladesh indicated that there was a positive effect of maternal education on child development and survival between age 6 and 37 months (28). Regardless of family resources, more-educated mothers can provide a more favourable environment for healthy child development (29).

In the present study, there was a positive association between early child development and economic status. Children from wealthy families were more likely to have early development than those from poor families. An earlier study showed that a larger wealth gap led to a greater difference in children's cognitive development (30). Research in rural Bangladesh has shown that poverty affects child growth (31), and worldwide, 250 million children aged $<5$ years live in poverty (30). A longitudinal research study from Bogota, Colombia showed that there was a positive association between developmental deficits and poverty (32).

Child nutritional status is an important factor in ECDI. We found that malnourished children were less likely to be developed than well-nourished children. In LMICs, millions of children aged $<5$ years struggle to achieve their potential for cognitive, language, social and emotional development (8). The World Health Organization has proposed that child development programmes be integrated into the care of children who are malnourished and sick. In child growth, nutritional supplements and relaxation play a crucial role (33). There is evidence to indicate that nutritional interventions are mandatory in the ECD process (9).

Children who read $\geq 3$ books in their early years show signs of early development more than children who do not read or who are read to. We found that children were more cognitively developed if they read $\geq 3$ books between 3 and 5 years of age. Previous studies have shown that the combination of books and reading instructions significantly improves the cognitive ability of adolescents (34). In another study, there was an association between children's reading behaviour and learning performance (35).

Our study had some limitations. First, we did not include equal numbers of children from each country. 
Table 4 Binary logistic regression analysis showing the effect of ECDI among children aged 3-5 years by background characteristics in Bangladesh, Costa Rica and Ghana

\begin{tabular}{|c|c|c|c|c|c|c|}
\hline \multirow[t]{3}{*}{ Characteristics } & \multicolumn{6}{|c|}{ ECDI } \\
\hline & \multicolumn{2}{|c|}{ Bangladesh } & \multicolumn{2}{|c|}{ Costa Rica } & \multicolumn{2}{|c|}{ Ghana } \\
\hline & $\begin{array}{l}\text { OR } \\
\text { (P) }\end{array}$ & $95 \% \mathrm{CI}$ & $\begin{array}{l}\text { OR } \\
\text { (P) }\end{array}$ & $95 \% \mathrm{CI}$ & $\begin{array}{l}\text { OR } \\
\text { (P) }\end{array}$ & $95 \% \mathrm{CI}$ \\
\hline \multicolumn{7}{|l|}{ Child age } \\
\hline 36-47 months & $\begin{array}{c}0.51 \\
(<0.001)\end{array}$ & $0.46-0.56$ & $\begin{array}{c}0.85 \\
(<0.001)\end{array}$ & $0.82-0.88$ & $\begin{array}{c}0.57 \\
(<0.001)\end{array}$ & $0.49-0.68$ \\
\hline 48-59 months (ref.) & 1 & & 1 & & 1 & \\
\hline \multicolumn{7}{|l|}{ Child sex } \\
\hline Male & $\begin{array}{c}0.69 \\
(<0.001)\end{array}$ & $0.62-0.76$ & $\begin{array}{c}0.50 \\
(<0.001)\end{array}$ & $0.48-0.52$ & $\begin{array}{c}0.72 \\
(<0.001)\end{array}$ & $0.61-0.85$ \\
\hline Female (ref.) & 1 & & 1 & & 1 & \\
\hline \multicolumn{7}{|l|}{ Residence } \\
\hline Urban & $\begin{array}{l}1.04 \\
(0.60)\end{array}$ & $0.90-1.19$ & $\begin{array}{c}0.76 \\
(<0.001)\end{array}$ & $0.73-0.79$ & $\begin{array}{c}1.83 \\
(<0.001)\end{array}$ & $1.50-2.22$ \\
\hline Rural (ref.) & 1 & & 1 & & 1 & \\
\hline \multicolumn{7}{|l|}{ Maternal education } \\
\hline None & $\begin{array}{c}0.66 \\
(<0.001)\end{array}$ & $0.56-0.77$ & $\begin{array}{c}0.38 \\
(<0.001)\end{array}$ & $\begin{array}{l}0.35-0.41 \\
0.63-0.69\end{array}$ & $\begin{array}{c}0.50 \\
(<0.001)\end{array}$ & $0.35-0.70$ \\
\hline Primary & $\begin{array}{c}0.73 \\
(<0.001)\end{array}$ & $0.65-0.82$ & $\begin{array}{c}0.66 \\
(<0.001)\end{array}$ & & $\begin{array}{c}0.59 \\
(0.001)\end{array}$ & $0.43-0.82$ \\
\hline Secondary and above (ref.) & 1 & & 1 & & 1 & \\
\hline \multicolumn{7}{|l|}{ Economic status } \\
\hline Poor & $\begin{array}{c}0.70 \\
(<0.001)\end{array}$ & $0.62-0.80$ & $\begin{array}{c}0.57 \\
(<0.001)\end{array}$ & $\begin{array}{l}0.54-0.60 \\
0.41-0.45\end{array}$ & $\begin{array}{c}0.54 \\
(<0.001)\end{array}$ & $0.42-0.68$ \\
\hline Middle & $\begin{array}{l}0.84 \\
(0.02)\end{array}$ & $0.72-0.97$ & $\begin{array}{c}0.43 \\
(<0.001)\end{array}$ & & $\begin{array}{c}0.59 \\
(<0.001)\end{array}$ & $0.46-0.76$ \\
\hline Rich (ref.) & 1 & & 1 & & 1 & \\
\hline \multicolumn{7}{|l|}{ Child nutritional status } \\
\hline Severely malnourished & $\begin{array}{l}0.76 \\
(0.02)\end{array}$ & $0.61-0.96$ & $\begin{array}{c}0.09 \\
(<0.001)\end{array}$ & $\begin{array}{l}0.07-0.12 \\
0.72-0.89\end{array}$ & $\begin{array}{c}0.74 \\
(0.39)\end{array}$ & $0.37-1.48$ \\
\hline Moderately malnourished & $\begin{array}{c}0.91 \\
(0.13)\end{array}$ & $0.81-1.03$ & $\begin{array}{c}0.80 \\
(<0.001)\end{array}$ & & $\begin{array}{c}0.75 \\
(0.03)\end{array}$ & $0.58-0.98$ \\
\hline Nourished (ref.) & 1 & & 1 & & 1 & \\
\hline \multicolumn{7}{|l|}{ Reading children's books } \\
\hline$\geq 3$ & $\begin{array}{c}1.62 \\
(<0.001)\end{array}$ & $1.35-1.95$ & $\begin{array}{c}2.44 \\
(<0.001)\end{array}$ & $2.35-2.54$ & $\begin{array}{c}1.48 \\
(0.03)\end{array}$ & $1.04-2.11$ \\
\hline$<3$ (ref.) & 1 & & 1 & & 1 & \\
\hline \multicolumn{7}{|l|}{ Maternal functional difficulty } \\
\hline Yes & $\begin{array}{c}0.64 \\
(0.01)\end{array}$ & $0.46-0.91$ & $\begin{array}{c}0.61 \\
(<0.001)\end{array}$ & $0.58-0.65$ & $\begin{array}{c}0.47 \\
(<0.001)\end{array}$ & $0.35-0.64$ \\
\hline No (ref.) & 1 & & 1 & & 1 & \\
\hline
\end{tabular}

$\mathrm{CI}=$ confidence interval; $E C D I=$ Early Child Development Index; $\mathrm{OR}=$ odds ratio .

However, MICS data were not available for all countries and it proved too difficult to obtain equal sample sizes during the MICS6 survey. Second, the cross-sectional study design was not suitable for identifying the causeand-effect relationship between ECDI and its selected risk factors.

\section{Conclusion}

ECD is a key factor in the initial life of a child and has a significant impact on a nation. This study concluded that child sex, maternal education, economic status, child nutritional status, reading children's books, and maternal functional difficulties had significant effects on the
ECDI in Bangladesh, Costa Rica and Ghana. Our findings may have important implications for international as well as national goals (SDG Target 4.2). Target 4.2 will be achieved only if policy-makers implement several strategies to develop child growth by 2030 . We recommend that governments should initiate different programmes for child development at an early stage by enhancing maternal education and improving nutritional status for all children, especially those from poor families. Interventions such as, child health services, education, poverty alleviation, and creating a conducive environment for mental development could reduce the developmental deficit among children aged $<5$ years from these selected countries. 


\section{Acknowledgement}

Special thank goes to the United Nations Children's Fund (UNICEF) for enabling us to use Multiple Indicator Cluster Survey data from Bangladesh, Costa Rica and Ghana for our study (http://mics.unicef.org/).

Funding: None.

Competing interests: None declared.

\section{Déterminants de l'indice de développement dans la petite enfance chez les enfants de moins de cinq ans au Bangladesh, au Costa Rica et au Ghana : étude comparative \\ Résumé}

Contexte: Le développement du jeune enfant est un facteur crucial qui influence la santé et le bien-être à l'âge adulte.

Objectifs : Déterminer l'influence des facteurs sociodémographiques sur l'indice de développement dans la petite enfance chez les enfants de moins de cinq ans.

Méthodes: L'analyse a été réalisée à partir de données d'études transversales menées dans le cadre des enquêtes en grappes à indicateurs multiples effectuées respectivement en 2019, 2017-2018 et 2018 au Bangladesh, au Ghana et au Costa Rica. Pour les trois pays, nous avons utilisé le test $\chi^{2}$ pour l'analyse bivariée et le modèle de régression logistique binaire pour l'analyse multivariée. Toutes les analyses statistiques ont été réalisées à l'aide des logiciels SPSS version 25 et $R$ version 4.0.0 d'IBM.

Résultats : L'âge et le sexe de l'enfant, suivis par le niveau d'éducation de la mère, la situation économique, l'état nutritionnel de l'enfant, la lecture de livres pour enfants et les difficultés fonctionnelles de la mère, correspondaient aux facteurs influençant le plus l'indice de développement du jeune enfant. Les enfants âgés de 36 à 47 mois affichaient de plus faibles chances de développement que ceux âgés de 48 à 59 mois, de même que les garçons par rapport aux filles au Bangladesh, au Costa Rica et au Ghana. Les enfants vivant en zone urbaine présentaient des chances de développement inférieures à celles des enfants des zones rurales au Costa Rica, tandis que la situation était inverse au Ghana.

Conclusion: Nous recommandons aux gouvernements de prendre les mesures nécessaires afin d'améliorer le développement et le bien-être des jeunes enfants dans les trois pays. Cela passe par le renforcement de l'accès à l'éducation et à une nutrition équilibrée, et par l'amélioration des conditions économiques.

$$
\begin{aligned}
& \text { محددات مؤشر النحاء في مرحلة الطفولة المبكرة في صفوف الأطفال الذين تقل أعمارهم عن } 5 \text { سنوات في بنجلاديش، } \\
& \text { وكوستاريكا، وغانا: دراسة مقارنة } \\
& \text { إكرام الحق، إسماعيل حسين، مليحة عفروج زينيا، رفعت حسن، إمرؤ القيس شودري }
\end{aligned}
$$

الخلفية: يمثل النهاء في مر حلة الطفولة المبكرة عاملا حاسًا يتحكم في صحة الأطفال ورفاههم في مر احل عمرهم اللاحقة.

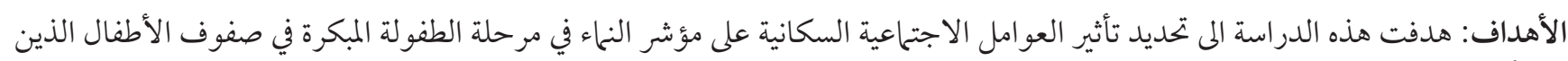

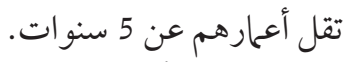

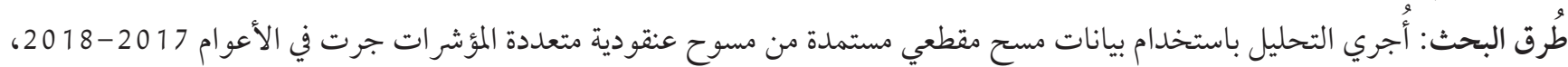

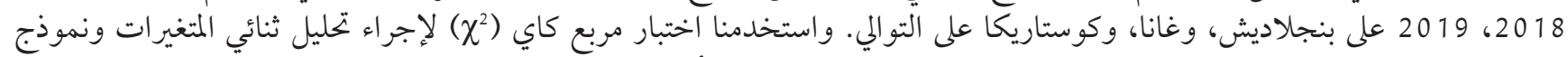

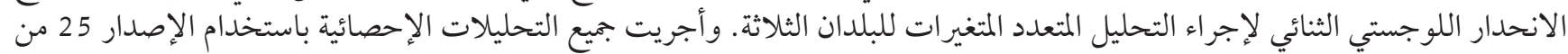

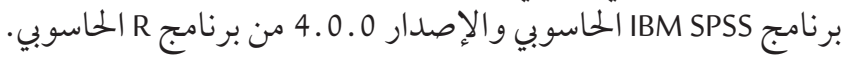

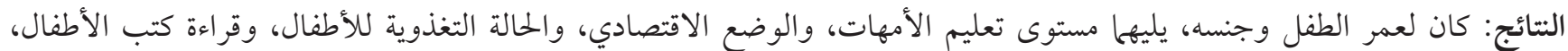

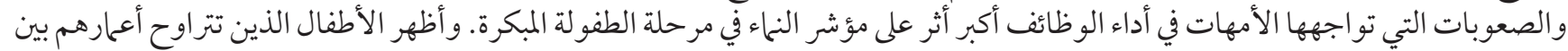

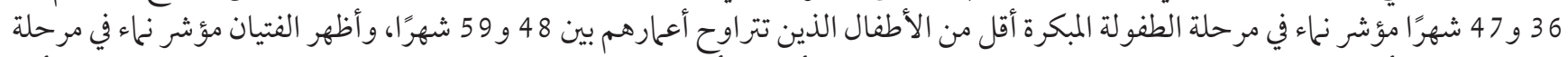

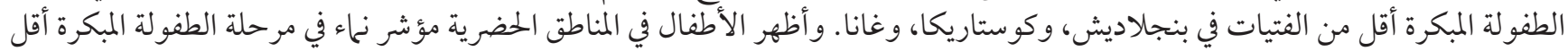
من نظيره في صفوف الأطفال في المناطق الريفية في كوستاريكا، وكنا، ولكنه كان أعلى في غانانا.

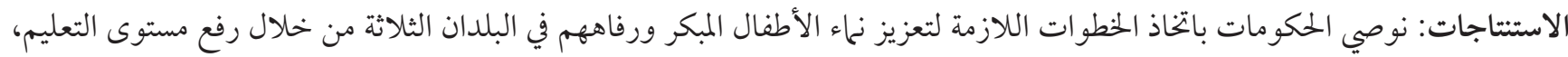
وتحسين الظروف الآقتصادية، وتوفير التغذية المتوازنة. 


\section{References}

1. Lerner RM. Concepts and theories of human development. Taylor \& Francis; 2015.

2. Sk R, Banerjee A, Mishra R, Barua S. Quality of care and early childhood developmental status in Nepal: a multilevel analysis. Early Child Dev Care. 2019;190(14):2264-77. https://doi.org/10.1080/03004430.2019.1570503

3. Britto PR, Lye SJ, Proulx K, Yousafzai AK, Matthews SG, Vaivada T, et al. Nurturing care: promoting early childhood development. Lancet. 2017 Jan 7;389(10064):91-102. https://doi.org/10.1016/So140-6736(16)31390-3 PMID:27717615

4. Hunter E. Costa Rica shows the way by providing pre-primary education for all children [website]. Their World; 2018 (https:// theirworld.org/news/costa-rica-shows-the-way-provides-pre-primary-education-for-every-child\#: :text=Costa\%20Rica\%20 has\%2obecome\%20a, accessed 2 August 2021).

5. Transforming our world: the 2030 Agenda for Sustainable Development. United Nations, Department of Economic and Social Affairs; 2015 (https://sustainabledevelopment.un.org/post2015/transformingourworld, accessed 2 August 2021).

6. Nurturing care for early childhood development a global framework for action and results. Geneva: World Health Organization; 2018 (https://www.who.int/maternal_child_adolescent/child/nurturing-care-framework-first-draft.pdf, accessed 18 November 2020).

7. Walker SP, Wachs TD, Grantham-McGregor S, Black MM, Nelson CA, Huffman SL, et al. Inequality in early childhood: risk and protective factors for early child development. Lancet. 2011 Oct 8;378(9799):1325-38. https://doi.org/10.1016/So140-6736(11)60555-2 PMID:21944375

8. Walker SP, Wachs TD, Meeks Gardner J, Lozoff B, Wasserman GA, Pollitt E, et al. Child development: risk factors for adverse outcomes in developing countries. Lancet. 2007 Jan 13;369(9556):145-57. https://doi.org/10.1016/So140-6736(07)60076-2 PMID:17223478

9. Grantham-McGregor S, Cheung YB, Cueto S, Glewwe P, Richter L, Strupp B. Developmental potential in the first 5 years for children in developing countries. Lancet. 2007 Jan 6;369(9555):60-70. https://doi.org/10.1016/So140-6736(07)60032-4 PMID:17208643

10. Friedman J, Sturdy J. The influence of economic crisis on early childhood development: a review of pathways and measured impact. In: Alderman H, editor. No small matter: the impact of poverty, shocks, and human capital investments in early childhood development. World Bank; 2011:51-83.

11. Sheffield PE, Landrigan PJ. Global Climate change and children's health: threats and strategies for prevention. Environ Health Perspect. 2011 Mar;119(3):291-8. https://doi.org/10.1289/ehp.1002233 PMID:20947468

12. Engle PL, Black MM, Behrman JR, Cabral de Mello M, Gertler PJ, Kapiriri L, et al. Strategies to Avoid the Loss of Developmental Potential in More than 200 Million Children in the Developing World. Lancet. 2007 Jan 20;369(9557):229-42. https://doi. org/10.1016/So140-6736(07)60112-3 PMID:17240290

13. Bowman BT, Donovan S, Burns MS, National Research Council (US). Committee on Early Childhood Pedagogy. Eager to learn: educating our preschoolers. Washington, Dc: National Academy Press; 2001.

14. Sylva K, Melhuish E, Sammons P, Siraj-Blatchford I, Taggart B. The Effective Provision of Pre-School Education (EPPE) Project: findings from pre-school to end of key stage 1. 2004 (https://dera.ioe.ac.uk/8543/7/SSU-SF-2004-01.pdf, accessed 3 August 2021).

15. San Francisco AR, Arias M, Villers R. Quality early childhood education in Costa Rica? Policy, practice, outcomes and challenges. Early Years. 2005;25(2):113-27. https://doi.org/10.1080/09575140500127956

16. Apolitical. Should preschool be mandatory? Costa Rica thinks so [website]. 2018 (https://apolitical.co/en/solution_article/shouldpreschool-be-mandatory-costa-rica-thinks-so, accessed 3 August 2021).

17. Early childhood development [website]. UNICEF; 2012 (https://www.unicef.org/early-childhood-development, accessed 3 August 2021).

18. Bago J-L, Ouédraogo M, Akakpo K, Lompo ML, Souratié W dite M, Ouédraogo E. Early childhood education and child development: new evidence from Ghana. Child Youth Services Rev. 2020; 108:104620. https://doi.org/10.1016/j.childyouth.2019.104620

19. Multiple Indicator Cluster Survey (MICS 2017/18), survey findings report. Accra: Ghana Statistical Service; 2018.

20. Sikder S, Banu LFA. Early childhood care and education in Bangladesh: a review of policies, practices and research. In: Fleer M, van Oers B, editors. International Handbook of Early Childhood Education. Springer; 2018;569-87.

21. Hamadani JD, Nahar B, Huda SN, Tofail F. Integrating early child development programs into health and nutrition services in Bangladesh: benefits and challenges. Ann N Y Acad Sci. 2014 Jan;1308(1):192-203. https://doi.org/10.1111/nyas.12366 PMID:24571219

22. Bangladesh Bureau of Statistics (BBS) and UNICEF Bangladesh. Progotir pathey, Bangladesh Multiple Indicator Cluster Survey 2019, survey findings report. Dhaka: BBS; 2019 (https://www.unicef.org/bangladesh/media/3281/file/Bangladesh\%202019\%20 MICS\%20Report_English.pdf, accessed 3 August 2021).

23. Ministerio de Salud (MS), Instituto Nacional de Estadística y Censos (INEC) y Fondo de las Naciones Unidas para la Infancia (UNICEF). Encuesta de Mujeres, Niñez y Adolescencia (EMNA), Informe de resultados de la encuesta. San José, Costa Rica; 2018 (https://www.unicef.org/costarica/media/436/file/Encuesta-de-mujeres-ninez-y-adolescencia-2018.pdf, accessed 3 August 2021).

24. Palloni G. Childhood health and the wantedness of male and female children. J Dev Econ. 2017;126:19-32. https://doi.org/10.1016/j. jdeveco.2016.11.005 
25. Little M, Kohm A, Thompson R. The impact of residential placement on child development: research and policy implications. Int J Soc Welf. 2005 Jul;14(3):200-9. https://doi.org/10.1111/j.1468-2397.2005.00360.x

26. Smith LC, Ruel MT, Ndiaye A. Why is child malnutrition lower in urban than in rural areas? Evidence from 36 developing countries. World Dev. 2005 Aug;33(8):1285-305. https://doi.org/10.1016/j.worlddev.2005.03.002

27. Coleman M, Ganong LH, Clark JM, Madsen R. Parenting perceptions in rural and urban families: is there a difference? J Marriage Fam. 1989 May;51(2):329-35. https://doi.org/10.2307/352496

28. Bhuiya A, Streatfield K. Mothers' education and survival of female children in a rural area of Bangladesh. Popul Stud. 1991 Jul;45(2):253-64. https://www.jstor.org/stable/2174782

29. Cui Y, Liu H, Zhao L. Mother's education and child development: evidence from the compulsory school reform in China. J Comp Econ. 2019 Sep;47(3):669-92. https://doi.org/10.1016/j.jce.2019.04.001

30. Black MM, Walker SP, Fernald LCH, Andersen CT, DiGirolamo AM, Lu C, et al. Early childhood development coming of age: science through the life course. Lancet. 2017 Jan 7;389(10064):77-90. https://doi.org/10.1016/So140-6736(16)31389-7 PMID:27717614

31. Hamadani JD, Mehrin SF, Tofail F, Hasan MI, Huda SN, Baker-Henningham H, et al. Integrating an early childhood development programme into Bangladeshi primary health-care services: an open-label, cluster-randomised controlled trial. Lancet Glob Health. 2019 Mar 1;7(3):e366-75. https://doi.org/10.1016/S2214-109X(18)30535-7

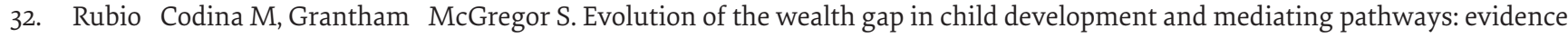
from a longitudinal study in Bogota, Colombia. Dev Sci. 2019 Sep;22(5):e12810. https://doi.org/10.1111/desc.12810

33. Aboud FE, Akhter S. A cluster-randomized evaluation of a responsive stimulation and feeding intervention in Bangladesh. Pediatrics. 2011 May;127(5):e1191-7. https://doi.org/10.1542/peds.2010-2160 PMID:21502222

34. Dickinson DK, Griffith JA, Golinkoff RM, Hirsh-Pasek K. How reading books fosters language development around the world. Child Dev Res. 2012;Article ID 602807. https://doi.org/10.1155/2012/602807

35. Dünser A, Hornecker E. An observational study of children interacting with an augmented story book. In: Pan Z, Zhang X, El Rhalibi A, Woo W, Li Y, editors. Technologies for e-learning and digital entertainment. Springer Nature; 2007:305-15. 